\author{
Lukasz Wściubiak \\ Uniwersytet Ekonomiczny \\ w Poznaniu
}

\title{
Przedsiębiorczość jako odpowiedź na narastającą turbulencję otoczenia współczesnych przedsiębiorstw
}

\section{Entrepreneurship as a response to the increasing turbulence of contemporary business environment}

\begin{abstract}
Streszczenie
Obserwowane na przełomie XX i XXI w. przemiany o charakterze społeczno-ekonomicznym, politycznym i technologicznym doprowadziły do niespotykanego wcześniej wzrostu złożoności i burzliwości otoczenia, w którym przychodzi funkcjonować współczesnym przedsiębiorstwom. Coraz częściej klasyczne koncepcje zarządzania, oparte m.in. na konstruowaniu długookresowych planów oraz ich konsekwentnej realizacji, nie wytrzymują konfrontacji z realiami gospodarki. W takiej sytuacji konieczne staje się poszukiwanie nowych instrumentów zarządzania: skutecznych a jednocześnie możliwie prostych i zrozumiałych dla praktyków.

W artykule zwrócono uwagę na możliwości odwołania się do zasad przedsiębiorczości - rozumianej jako umiejętność dostrzegania sposobności w otoczeniu przedsiębiorstwa oraz ich wykorzystywania - jako remedium na problemy związane z zarządzaniem współczesnymi podmiotami gospodarczymi, niezależnie od ich wielkości czy profilu działalności.

W celu lepszego zobrazowania omawianych zagadnień w artykule przedstawiono także analizę przypadku firmy InPost, największego niezależnego operatora pocztowego na rynku polskim, z powodzeniem wykorzystującego w swojej działalności szereg rozwiązań o charakterze innowacyjnym.
\end{abstract}

\begin{abstract}
The transformation of the socio-economic, political and technological developments, which are observed at the turn of the century, led to an unprecedented increase in the complexity and turbulence of the environment in which enterprises operate today. More and more often, the traditional concepts of management based on the construction of long-term plans and their consistent implementation, among others, cannot withstand a confrontation with realities of the economy. In such a situation, it becomes necessary to look for new management tools: effective, but as simple and comprehensible as possible for practitioners.

The paper draws attention to the possibility of recourse to the principles of entrepreneurship - understood as the ability to see opportunities in the business environment, and their use as a remedy to problems associated with managing today's business entities, regardless of their size or profile. In order to illustrate these issues in a better way, the paper presents a case study of InPost, the largest independent postal operator on the Polish market, successfully using a number of significant innovations in its business.
\end{abstract}

Słowa kluczowe: burzliwe otoczenie; innowacja; przedsiębiorczość; zarządzanie przedsiębiorstwem Key words: enterprise management; entrepreneurship; innovation; turbulent environment 


\section{Wprowadzenie}

Globalny kryzys gospodarczy w sposób szczególny skłania do pogłębionej refleksji nad przemianami zachodzącymi w otoczeniu współczesnych przedsiębiorstw. Rzeczywistość gospodarcza początku XXI w. naznaczona jest bowiem coraz większą niepewnością, niejednoznacznością i nieprzewidywalnością. Co więcej, nic nie wskazuje, aby obraz ten w najbliższej przyszłości mógł ulec istotnej zmianie. Wydaje się więc, że obserwowany obecnie okres zawirowań i turbulencji $\mathrm{w}$ otoczeniu przedsiębiorstw nie jest jakimś przejściowym epizodem, a raczej pewnego rodzaju „nową normalnością” (Kotler, Caslione, 2009: 31-33).

Sytuacja ta stawia również zupełnie nowe wyzwania przed współczesnym zarządzaniem. Coraz częściej bowiem klasyczne koncepcje, oparte m.in. na konstruowaniu długookresowych planów oraz ich konsekwentnej realizacji, nie wytrzymują konfrontacji z realiami gospodarki. W takiej sytuacji konieczne staje się poszukiwanie zupełnie nowych instrumentów zarządzania: skutecznych a jednocześnie możliwie prostych i zrozumiałych dla praktyków.

Celem niniejszego artykułu jest ukazanie przedsiębiorczości jako swoistego remedium na problemy związane z zarządzaniem współczesnymi przedsiębiorstwami, wynikające z niespotykanego nigdy wcześniej wzrostu burzliwości otoczenia oraz braku skutecznych a jednocześnie prostych instrumentów zarządzania.

\section{Zmiana charakteru otoczenia współczesnych przedsiębiorstw}

Pod pojęciem otoczenie przedsiębiorstwa należy rozumieć całokształt zjawisk, procesów i instytucji kształtujących jego stosunki wymienne, możliwości sprzedaży produktów, zakresy działania oraz perspektywy rozwojowe (Penc, 2003: 14), czyli - najogólniej rzecz ujmując zespół warunków jego funkcjonowania. W literaturze przedmiotu ugruntowany został podział otoczenia przedsiębiorstwa na otoczenie bliższe (nazywane także mikrootoczeniem lub otoczeniem konkurencyjnym) oraz otoczenie dalsze (określane z reguły mianem makrootoczenia). Otoczenie konkurencyjne przedsiębiorstwa tworzą jego klienci, dostawcy oraz istniejący bądź potencjalni konkurenci. Z kolei makrootoczenie kształtowane jest przez czynniki ekonomiczne, polityczne, społeczne, technologiczne, prawne oraz demograficzne (Gierszewska, Romanowska, 2009: 24). R. Wolański zwraca także uwagę na konieczność wyodrębnienia otoczenia finansowego przedsiębiorstwa, do którego zalicza m.in. szeroko rozumiane instytucje finansowe, podmioty zajmujące się finansowaniem działalności gospodarczej oraz regulacje prawne tworzone przez władze państwowe i samorządowe (Wolański, 2013: 48-51). Propozycja ta wydaje się być godna rozważenia, przede wszystkim ze względu na obserwowane w ostatnich latach zawirowania na rynkach finansowych oraz ich niekorzystny wpływ na działalność zdecydowanej większości podmiotów gospodarczych.

Nasilające się zmiany w otoczeniu przedsiębiorstw nie są zjawiskiem zupełnie nowym, obserwuje się je bowiem już od lat 80. XX w. (zob. Ansoff, 1985; Drucker, 1995). Jednak na przełomie tysiącleci, wobec kumulacji zachodzących zmian, turbulentność otoczenia stała się jedną z najbardziej charakterystycznych cech procesu gospodarowania, stawiając współczesne przedsiębiorstwa w obliczu wielu wyzwań i niewiadomych. Należy jednak pamiętać, że zmienność otoczenia niesie za sobą także szereg sposobności i tylko od podejmowanych przez przedsiębiorstwo działań zależy, czy zostaną one w należyty sposób wykorzystane (Sudoł, 2006: 58).

W tym kontekście, w sposób całkowicie naturalny, pojawia się pytanie o przyczyny takiego stanu rzeczy. Jako najbardziej oczywistą i narzucającą się odpowiedź można tutaj wskazać postępującą globalizację oraz rozwój nowych technologii (w tym internetu), jednak głębsza analiza literatury przedmiotu ukazuje nieco bardziej złożony obraz czynników sprawczych. 
Przykładowo, E. Mączyńska przywołuje interesującą koncepcję L.C. Thurowa, w myśl której obserwowany obecnie stan naruszenia równowagi otoczenia spowodowany jest przez równoczesne oddziaływanie pięciu głównych sił przemian (Mączyńska, 2010: 203):

- upadek komunizmu, który przyczynił się do rozpowszechnienia bezkrytycznej wiary w doktrynę neoliberalną;

- rozwój gospodarki opartej na wiedzy;

- zmiany demograficzne: gwałtowny przyrost ludności w krajach najbiedniejszych, starzenie się społeczeństw bogatych oraz niespotykany nigdy wcześniej wzrost mobilności ludności;

- postępująca globalizacja oraz związana z nią rosnąca złożoność i nieprzejrzystość powiązań gospodarczych;

- stopniowa utrata hegemonii przez Stany Zjednoczone, dominujące dotychczas światowe supermocarstwo.

Spośród czynników wymienianych w pracach innych autorów (zob. Jasiński, 2005; Kotler, Caslione, 2009) warto również zwrócić uwagę na następujące zjawiska:

- zmianę wzorców konsumpcji, wzrost oczekiwań klientów (m.in. w zakresie ceny, jakości i walorów użytkowych) oraz coraz krótsze cykle życia produktów;

- rosnące znaczenie ekologii w procesach gospodarowania, będące wynikiem zarówno rosnącej świadomości konsumentów, jak i nieuchronnego wyczerpywania się dostępnych zasobów naturalnych;

- liberalizację handlu międzynarodowego oraz nasilenie konkurencji w skali globalnej;

- ukształtowanie się nowej struktury wielu sektorów w wyniku konsolidacji przedsiębiorstw (fala fuzji i przejęć) oraz rozwoju korporacji transnarodowych;

- niestabilność rynków kapitałowych (wywołaną m.in. wzrostem liczby transakcji o charakterze spekulacyjnym) oraz spektakularne bankructwa wielkich firm;

- zmiany w układzie geopolitycznym (m.in. wzrost znaczenia krajów azjatyckich takich jak Chiny i Indie) oraz światowy terroryzm.

Podsumowując powyższe rozważania, można zatem stwierdzić, że burzliwość otoczenia współczesnych przedsiębiorstw wynika z faktu, że zachodzi w nim coraz więcej zmian o trudnych do przewidzenia następstwach. Równocześnie zaobserwować można także pewnego rodzaju „kompresję czasu”, która przejawia się coraz szybszym tempem zachodzących zmian, co w konsekwencji pozostawia przedsiębiorstwu coraz mniej czasu na dostosowanie do nowych warunków funkcjonowania. Pomiędzy przedsiębiorstwem a jego otoczeniem zachodzą coraz silniejsze i bardziej wielostronne interakcje (Sudoł, 2006: 63), wynikające m.in. z konieczności rozszerzania zakresu współpracy z innymi podmiotami gospodarczymi.

\section{Istota i sposób pojmowania przedsiębiorczości}

Obserwowany w ostatnich dziesięcioleciach wzrost zainteresowania problematyką przedsiębiorczości związany jest niewątpliwie ze zmianami zachodzącymi w otoczeniu współczesnych przedsiębiorstw, szczegółowo opisanymi w poprzednim podrozdziale. Należy jednak podkreślić, że przedsiębiorczość nie jest pojęciem zupełnie nowym. W piśmiennictwie ekonomicznym jest ono obecne już od ponad 250 lat, a jego początki sięgają prac żyjącego na przełomie XVII i XVIII w. R. Cantillona (Matusiak, 2006: 16-17).

Przedsiębiorczość jest bez wątpienia zjawiskiem wielowymiarowym i złożonym, które nieustannie ewoluuje, tworząc coraz to nowe formy i typy zachowań. Tym samym pozostaje ono w kręgu zainteresowań wielu dyscyplin naukowych, takich jak: ekonomia, nauki o zarządzaniu, socjologia, psychologia, prawo, pedagogika czy etyka (Matusiak, 2006: 15). Jak do tej pory nie zostały ukształtowane także kompleksowe ramy teoretyczne, służące głębszemu 
poznaniu problematyki przedsiębiorczości (Bławat, 2003: 10-11). W literaturze przedmiotu spotkać można wręcz pogląd, wyrażany m.in. przez S. Sudoła (2008: 20-21), że zbudowanie jednej, spójnej teorii przedsiębiorczości jest wręcz niemożliwe. Zdaniem cytowanego autora, okoliczność ta nie powinna jednak zniechęcać do podejmowania wysiłków zmierzających do wyjaśnienia fenomenu przedsiębiorczości z wielu różnych perspektyw badawczych (np. od strony psychologii człowieka, zjawisk obserwowanych wewnątrz organizacji, uwarunkowań kulturowych czy też mechanizmów społeczno-gospodarczych zachodzących w otoczeniu).

Ze względu na wyjątkowe bogactwo i różnorodność omawianego zjawiska wielu autorów wyodrębnia także szereg typów przedsiębiorczości, choć trzeba wyraźnie zaznaczyć, że proponowane podziały nacechowane są zwykle dużą dozą subiektywizmu i mają przede wszystkim charakter poglądowy. Przykładowo, A. Kurczewska (2013: 38), stosując kilka różnych kryteriów podziału, wyróżnia następujące typy przedsiębiorczości:

- w zależności od charakteru działalności: przedsiębiorczość technologiczna, przedsiębiorczość międzynarodowa, przedsiębiorczość intelektualna, przedsiębiorczość akademicka, przedsiębiorczość ekologiczna;

- W zależności od osoby przedsiębiorcy: przedsiębiorczość kobiet, przedsiębiorczość rodzinna, przedsiębiorczość seniorów, przedsiębiorczość imigrantów;

- w zależności od typu zachowań: przedsiębiorczość zespołowa, przedsiębiorczość będąca stylem życia, przedsiębiorczość seryjna;

- w zależności od poziomu rozwoju firmy: przedsiębiorczość typu start-up, przedsiębiorczość w firmach o silnym wzroście (gazele biznesu).

Współczesne rozważania dotyczące przedsiębiorczości koncentrują się wokół trzech głównych nurtów, w ramach których akcentuje się (Blaug, 1994: 470-472): zdolność do wprowadzania innowacji (J.A. Schumpeter), umiejętność działania w warunkach niepewności (F. Knight) oraz równoważenie rynku przez dostrzeganie i wykorzystywanie szans pojawiających się w otoczeniu (I. Kirzner). Warto jednak zauważyć, że w praktyce podejścia te, choć stanowią odrębne koncepcje teoretyczne, mogą być bardzo trudne do rozgraniczenia.

Jednoznaczne zdefiniowanie pojęcia przedsiębiorczość jest zatem sprawą dość złożoną. Warto przy tym zwrócić uwagę, że zarówno w literaturze przedmiotu, jak i w rozumieniu potocznym, termin ten bardzo często jest utożsamiany z zespołem działań związanych z uruchamianiem nowego przedsięwzięcia gospodarczego (zob. Targalski, 2009; Gaweł, 2013). Przedsiębiorczość nie ogranicza się jednak wyłącznie do procesu powstawania czy też zarządzania małymi i średnimi przedsiębiorstwami. Coraz częściej jest ona bowiem postrzegana jako skuteczne narzędzie transformacji organizacji już istniejących, niezależnie od ich wielkości (Bratnicki, 2007: 60). Dlatego też dla potrzeb niniejszej pracy przedsiębiorczość definiowana jest jako umiejętność dostrzegania sposobności w otoczeniu przedsiębiorstwa oraz ich wykorzystywania. Bardzo podobny sposób postrzegania przedsiębiorczości można spotkać m.in. w pracy S. Shane'a i S. Venkataramana (2000). W takim ujęciu przedsiębiorczość może być postrzegana jako specyficzny styl zarządzania, zorientowany na wykorzystywanie szans i wprowadzanie zmian (Wickham, 2004 za: Glinka, 2008: 18-19).

\section{Innowacja jako narzędzie przedsiębiorczości}

Wielu autorów podkreśla bardzo silne związki łączące przedsiębiorczości z innowacjami. Warto w tym miejscu przywołać chociażby stanowisko P.F. Druckera (1992: 39), który uważał innowację za specyficzne narzędzie przedsiębiorczości i działanie nadające zasobom nowe możliwości tworzenia bogactwa. Przedsiębiorczość stanowi zatem impuls oraz siłę napędową zmian w gospodarce. 
Nie wdając się w głębszą dyskusję na temat występujących w literaturze przedmiotu definicji pojęcia innowacji, stwierdzić należy, że obecnie upowszechniło się bardzo szerokie rozumienie tego pojęcia. Według powszechnie uznawanego podręcznika metodologicznego OECD i Eurostatu, innowacja to wdrożenie nowego bądź istotnie ulepszonego produktu lub procesu, nowej metody marketingowej albo nowej metody organizacyjnej w praktyce gospodarczej, organizacji miejsca pracy czy stosunkach z otoczeniem. Wprowadzane rozwiązania muszą się odznaczać nowością przynajmniej w skali przedsiębiorstwa. W tym ujęciu do innowacji zalicza się zatem zarówno produkty, procesy i metody, które dana firma opracowała jako pierwsza, jak i te, które zostały przyswojone od innych podmiotów (Podręcznik Oslo, 2008: 49).

Takie podejście nie wynika zapewne z chęci umniejszania znaczenia rozwiązań o charakterze pionierskim. Wypada bowiem zauważyć, że we współczesnej gospodarce coraz większą rolę odgrywają innowacje oparte na naśladownictwie cudzych pomysłów. Pozwalają one na szerokie upowszechnienie postępu związanego z wprowadzeniem pierwotnej, oryginalnej innowacji, a w wielu wypadkach - także na jej udoskonalenie. Co ciekawe, także wśród największych korporacji można spotkać przypadki przedsiębiorstw, które choć nie były autorami pionierskich, przełomowych koncepcji to jednak zdołały osiągnąć pozycję światowych liderów dzięki umiejętności pełnego wykorzystania potencjału cudzych rozwiązań (Conway, Steward, 2009: 222-229).

Z punktu widzenia tematu podjętego w niniejszej pracy, warto zwrócić uwagę na kilka istotnych zjawisk, nieodłącznie związanych z problematyką innowacji. W pierwszej kolejności stwierdzić należy, że jakkolwiek innowacje są niezbędnym instrumentem w walce o przetrwanie przedsiębiorstwa, to jednak samo podjęcie aktywności w tym zakresie nie gwarantuje końcowego sukcesu. Wiele przedsięwzięć innowacyjnych kończy się bowiem niepowodzeniem. Przedsiębiorstwo może zostać zmuszone do zaniechania prac związanych z innowacją praktycznie na każdym etapie, co najczęściej wynika z niemożności zrealizowania pierwotnych założeń techniczno-ekonomicznych projektu, braku niezbędnych zasobów (w szczególności zaś środków finansowych), zmiany uwarunkowań rynkowych lub innych nieprzewidzianych zdarzeń. Co więcej, tylko niektóre z wprowadzanych innowacji spotykają się z akceptacją rynku i odnoszą sukces komercyjny (Vahs, Burmester, 2005: 74). Dlatego też przedsiębiorstwo powinno podejmować współpracę z innymi podmiotami gospodarczymi, instytucjami otoczenia biznesu czy placówkami naukowo-badawczymi. Zasadniczym celem takiej współpracy jest chęć zwiększenia potencjału innowacyjnego przedsiębiorstwa, przejawiająca się w możliwości wykorzystania zasobów, które są nieobecne lub słabo rozwinięte w przedsiębiorstwie (Popławski, 2008: 20-21). Do podstawowych korzyści płynących ze współpracy w dziedzinie innowacji należy zaliczyć: możliwość redukcji ryzyka i kosztów związanych z przedsięwzięciem innowacyjnym, możliwość osiągnięcia korzyści ekonomiki skali w produkcji oraz skrócenie czasu niezbędnego do opracowania i wdrożenia innowacji (Dodgson, Gann, Salter, 2008: 147-149).

Pewnego rodzaju paradoksem jest także fakt, że innowacje - choć stanowią odpowiedź przedsiębiorstwa na zmiany zachodzące w otoczeniu - same przyczyniają się do dalszego wzrostu jego turbulentności. Dzieje się tak za sprawą mechanizmu „twórczej destrukcji”, którego intensyfikację i umiędzynarodowienie obserwuje się w dobie rewolucji informatycznej (Zorska, 2011: 51). Innymi słowy, oddziaływanie innowacji na współczesną gospodarkę staje się coraz silniejsze i coraz częściej - w sposób wymuszony - prowadzi do kompleksowego przeobrażenia dotychczasowego modelu biznesu. Przykładowo, rozwój gospodarki elektronicznej doprowadził do paradoksalnej sytuacji, w której coraz więcej przedsiębiorstw może prowadzić zyskowną działalność, dostarczając swoim klientom znaczną część produktów i usług nieodpłatnie (zob. Anderson, 2011) 


\section{Przedsiębiorczy menedżer w przedsiębiorczej organizacji}

W najbardziej rozpowszechnionym i niejako klasycznym ujęciu menedżer to najemny profesjonalista, który w imieniu właściciela realizuje proces zarządzania przedsiębiorstwem. Od menedżera oczekuje się przede wszystkim specjalistycznej wiedzy oraz odpowiedniego doświadczenia w rozwiązywaniu typowych problemów biznesowych. Niejednokrotnie można spotkać się wręcz z opinią, że jest to pewnego rodzaju administrator powierzonego majątku, poszukujący racjonalnych - aczkolwiek dość odległych od optymalnych - sposobów wykorzystania zasobów przedsiębiorstwa.

Zdaniem K. Obłója (2007: 91-93) można jednak wskazać dwa zasadnicze powody, dla których menedżerowie coraz częściej będą musieli w swoich działaniach upodabniać się do „rasowych” przedsiębiorców:

- dobre, profesjonalne zarządzanie powoli staje się normą w większości przedsiębiorstw i tym samym nie wystarcza już do osiągnięcia znaczącej przewagi nad konkurentami;

- zbyt duża liczba firm obecnych na rynku zwiększa prawdopodobieństwo wybuchu wojny cenowej - konieczne staje się zatem poszukiwanie bardziej wyrafinowanych instrumentów konkurowania.

Dla wielu menedżerów sytuacja ta oznacza jednak prawdziwą mentalną rewolucję, związaną z koniecznością przystosowania się do zupełnie innego tempa działania (szybkie podejmowanie decyzji, niejednokrotnie o charakterze strategicznym), zerwaniem z przywiązaniem do status quo (które odtąd będzie nieustannie podważane) czy też akceptacją podwyższonego poziomu ryzyka (Obłój, 2007: 93-94).

Przedsiębiorczy menedżer musi bowiem podejmować działania zorientowane na innowacje, które w największym stopniu decydują o możliwości wykorzystania szans pojawiających się w otoczeniu i tym samym przesądzają o przyszłości przedsiębiorstwa. Aby to osiągnąć, powinien on odznaczać się umiejętnościami w zakresie obserwacji zmian w strukturze rynku, analizy procesów zachodzących wewnątrz przedsiębiorstwa oraz zarządzania wiedzą (rozumianego jako pozyskiwanie i dzielenie się wiedzą oraz jej wykorzystywanie w procesie podejmowania decyzji). Do niezbędnych cech przedsiębiorczego menedżera należy zaliczyć ponadto: wiarę we własne możliwości, pozytywny stosunek do otaczającej rzeczywistości oraz dążenie do nieustannego rozwoju swojej osobowości, m.in. przez poszukiwanie nowych doświadczeń, przełamywanie utartych schematów oraz automatyzmu w działaniu, a także wyciąganie wniosków z popełnianych błędów (Wachowiak, 2007: 149-151).

Na konieczność propagowania postaw przedsiębiorczych wśród kadry menedżerskiej wskazuje także J. Cieślik (2011: 243-244), który przeciwstawia się dość powszechnemu w Polsce zjawisku „,biznesowego mazgajstwa”, rozumianemu jako ciągłe utyskiwanie na napotykane bariery o charakterze administracyjnym i biurokratycznym, korupcję czy wysokie podatki. Przywoływany autor, nie negując występowania tego rodzaju zjawisk w otoczeniu rodzimych przedsiębiorstw oraz mając świadomość istniejących uwarunkowań kulturowych, zwraca uwagę na potrzebę czerpania pozytywnych wzorców z amerykańskiego środowiska biznesu, w którym dominuje zupełnie odmienny sposób myślenia i postrzegania otaczającej rzeczywistości.

Głębokie przeobrażenia obserwuje się także w modelu funkcjonowaniu samych przedsiębiorstw. Tradycyjne organizacje, działające na podstawie sformalizowanych procedur i wieloszczeblowych struktur zarządzania nie są bowiem w stanie nadążyć za coraz szybciej zmieniającym się rynkiem (Foster, Kaplan, 2003: 34-36).

Turbulencje w otoczeniu przedsiębiorstwa stanowią przede wszystkim bardzo poważne wyzwanie dla zarządzania strategicznego. Wzrost niepewności oraz związane z tym trudności w prognozowaniu zjawisk zachodzących w otoczeniu podważają bowiem sens tworzenia 
strategii przedsiębiorstw w tradycyjnym, planistycznym ujęciu (Pierścionek, 2006: 24). Równocześnie jednak, jak wskazuje J. Bogdanienko (2008: 69-70), istnieje szereg przesłanek przemawiających za wytyczaniem ogólnych kierunków rozwoju firm w dłuższym horyzoncie czasowym:

- zainteresowanie przyszłością może pomóc przedsiębiorstwu w wyeliminowaniu niepotrzebnych błędów oraz ograniczeniu kosztów związanych z prowadzonymi procesami dostosowawczymi (np. w zakresie rozbudowy potencjału wytwórczego, kształtowania niezbędnych umiejętności i kompetencji czy też doskonalenia oferowanych produktów);

- konieczność koordynacji coraz bardziej złożonych sieci powiązań międzyorganizacyjnych (m.in. w zakresie działalności zaopatrzeniowej i wytwórczej) zmusza do skrupulatnej analizy uwarunkowań zewnętrznych i tym samym ogranicza możliwości wszelkiej improwizacji; - coraz częściej strategia przedsiębiorstwa - jeśli tylko zostanie sformułowana w jasny a jednocześnie odpowiednio atrakcyjny sposób - traktowana jest jako ważny instrument marketingowy, przyczyniający się do kształtowania korzystnego wizerunku firmy oraz integracji wszystkich grup interesariuszy.

Zdaniem W. Szymańskiego (2011: 162-163), coraz większą rolę w dostosowywaniu się przedsiębiorstw do zmiennego otoczenia odgrywa nie tylko wiedza i zdolności menedżerów, ale także intuicja, przypadek czy szczęście. Tym niemniej jednak przywoływany autor wskazuje na konieczność myślenia scenariuszowego, uznając rozpatrywanie tylko jednego wariantu przyszłości za przejaw niezdrowego optymizmu i nadmiernego ryzykanctwa. Z kolei R. Krupski (2005: 48-49) postuluje wprowadzenie uproszczonego, a co za tym także idzie bardziej elastycznego podejścia do strategii przedsiębiorstwa: rezygnację z wyznaczania precyzyjnych celów strategicznych (i zastępowanie ich kategoriami bardziej ogólnymi) oraz traktowanie strategii jako systemu pojedynczych, szybkich i czasem wielokierunkowych działań zorientowanych na wykorzystywanie identyfikowanych okazji.

W tych warunkach wyłania się model organizacji przyszłości, silnie nasyconej elementami przedsiębiorczości, tworzącej środowisko sprzyjające podejmowaniu inicjatywy (zarówno przez kadrę menedżerską, jak i pozostałych pracowników), a przede wszystkim przystosowanej do konkurowania w warunkach gospodarki XXI w. Syntetyczne porównanie najistotniejszych cech tradycyjnej organizacji biurokratycznej oraz organizacji przedsiębiorczej zaprezentowano w tab. 1 .

Tab. 1. Porównanie najważniejszych cech organizacji biurokratycznej i przedsiębiorczej

\begin{tabular}{|l|l|}
\hline \multicolumn{1}{|c|}{ Organizacja biurokratyczna } & \multicolumn{1}{c|}{ Organizacja przedsiębiorcza } \\
\hline przetrwanie i rozwój & maksymalizacja wartości \\
\hline trwałość & zmienność, adaptacyjność \\
\hline oparta na zasobach materialnych & oparta na zasobach intelektualnych \\
\hline osiąga zaplanowane cele & maksymalizuje szanse, minimalizuje zagrożenia \\
\hline działa w określonej domenie & stale redefiniuje domenę \\
\hline dąży do dominacji & dąży do przechwytywania wartości \\
\hline dąży do utrzymania równowagi & poszukuje możliwości zakłócenia równowagi („twórcza destrukcja”) \\
\hline hierarchiczna i sformalizowana & płaska struktura, swoboda działania \\
\hline specjalizacja & wielofunkcyjność, brak zakresów czynności \\
\hline kariera przez awans pionowy & kariera przez awans poziomy \\
\hline nagrody za poprawność i konformizm & nagrody za inicjatywę i kreatywność \\
\hline władza trwała i formalna & władza sytuacyjna oparta na wiedzy \\
\hline „wieczna” i stała & z założenia przejściowa i zmienna \\
\hline
\end{tabular}

Źródło: adaptacja własna na podstawie (Koźmiński, 2004: 168-169). 
Z oczywistych względów do przedstawionego powyżej wzorca organizacji przyszłości najłatwiej jest dostosować się małym i średnim przedsiębiorstwom. Tym niemniej jednak w dalszej części artykułu zaprezentowano - na zasadzie analizy przypadku - wybrane aspekty działalności firmy InPost, której już od jakiegoś czasu z powodzeniem udaje się stosować w praktyce reguły przedsiębiorczego działania.

\section{InPost: od „niewinnego” kawałka blachy do rewolucji na rynku usług kurierskich}

Przez długi czas znakiem rozpoznawczym firmy InPost, niezależnego operatora pocztowego wchodzącego w skład grupy kapitałowej Integer.pl, był kawałek metalowej blachy, umieszczany na odwrocie dostarczanych przesyłek listowych. Rozwiązanie to, z pozoru zupełnie absurdalne, było $\mathrm{w}$ istocie wybiegiem prawnym, mającym na celu ominięcie obowiązującego aż do 2013 r. monopolu Poczty Polskiej na dostarczanie najpopularniejszej kategorii przesyłek pocztowych - listów o wadze do $50 \mathrm{~g}$.

Ten niewątpliwie oryginalny, aczkolwiek bardzo kontrowersyjny, sposób dociążania zbyt lekkich przesyłek listowych doprowadził do kilkuletniego sporu sądowego z Pocztą Polską (InPost wygrywa z Pocztą spór o blaszki w 2013), wzbudzając wiele wątpliwości także wśród samych odbiorców przesyłek. Dlatego też po pewnym czasie firma zrezygnowała ze stosowania wzbudzających tyle emocji blaszek, zastępując je dużo bardziej praktycznym sposobem, polegającym na umieszczaniu wewnątrz przesyłek różnego rodzaju notesików reklamowych.

Nie wdając się w ocenę etyczną opisywanych praktyk, należy podkreślić, że choć spółce InPost udało się wprowadzić sporo ożywienia na rynku usług pocztowych oraz zmusić państwowego monopolistę do głębokiej zmiany modelu dotychczasowej działalności, to jednak próba podważenia supremacji Poczty Polskiej w najbardziej atrakcyjnym segmencie rynku nadawców masowych - z różnych względów nie mogła zakończyć się pełnym sukcesem. Niewątpliwym atutem państwowego giganta pozostaje bowiem bardzo rozległa sieć placówek pocztowych, a ponadto $\mathrm{w}$ dalszym ciągu może on korzystać $\mathrm{z}$ istotnych preferencji w zakresie podatku VAT (znaczna część usług Poczty Polskiej jest z niego zwolniona, podczas gdy podobne usługi świadczone przez innych operatorów obłożone są stawką 23\%). Interesom Poczty sprzyja także obecność wśród największych nadawców wielu instytucji państwowych (Miączyński, Kostrzewski, 2013).

W ostatnim czasie firma InPost wprowadza rewolucyjne wręcz zmiany na rynku przesyłek kurierskich, rozwijając sieć innowacyjnych urządzeń, nazywanych potocznie paczkomatami. Obecnie spotkać je można w większości dużych i średnich miast, położonych przy głównych szlakach komunikacyjnych. Ich lokalizacja nie jest zatem przypadkowa. Paczkomaty pojawiają się najczęściej w takich miejscach, jak stacje benzynowe czy okolice centrów handlowych. $Z$ jednej strony zapewnia to swobodny i nieskrępowany dostęp dla osób odbierających przesyłki, z drugiej zaś ułatwia ochronę przed ewentualnymi kradzieżami czy aktami wandalizmu.

Usługi świadczone za pośrednictwem paczkomatów zaprojektowane zostały przede wszystkim z myślą o dynamicznie rozwijającym się sektorze e-handlu. Możliwość odbioru zakupionych towarów za pośrednictwem wybranego paczkomatu oferuje obecnie coraz więcej sklepów internetowych. Podstawową zaletą opisywanego rozwiązania jest niewątpliwie związana z nim wygoda - adresat przesyłki może się zgłosić po nią w dogodnym dla siebie momencie (ma na to 72 godziny od chwili dostarczenia przesyłki do paczkomatu, o czym jest informowany poprzez wiadomość SMS oraz za pośrednictwem poczty elektronicznej). Pozwala to uniknąć kłopotliwego wyczekiwania na listonosza czy kuriera. Dzięki daleko posuniętej automatyzacji procesu nadawania i odbioru przesyłek, oferowane usługi są także znacznie tańsze od klasycz- 
nych przesyłek kurierskich, co jest szczególnie ważne dla osób dokonujących zakupów o stosunkowo niewielkiej wartości.

Korzystanie z paczkomatów napotyka także na pewne ograniczenia i niedogodności. Wprawdzie liczba tego rodzaju urządzeń w Polsce nieustannie rośnie, to jednak w dalszym ciągu pozostają one niedostępne - a nawet wręcz nieznane - dla mieszkańców wielu mniejszych miejscowości. Pewnym problemem może okazać się także ograniczona wielkość skrytek paczkowych, co znacząco utrudnia przesyłanie tą drogą większych gabarytowo przedmiotów. Wspomnieć należy również o barierach natury mentalnej: jak każde innowacyjne rozwiązanie, tak i paczkomaty mogą bowiem wzbudzać nieufność części potencjalnych użytkowników (np. ze względu na czysto hipotetyczne ryzyko podjęcia przesyłki przez osobę nieuprawnioną, potencjalne problemy związane z uszkodzeniem przesyłki, dostarczeniem niewłaściwej paczki, itp.).

Wizjonerskie plany Rafała Brzoski, założyciela firmy InPost i jednego ze 100 najbogatszych Polaków według magazynu Forbes (Pochłopień, 2013), nie ograniczają się jednak wyłącznie do podboju rynku polskiego. Przewiduje się, że dzięki nawiązaniu współpracy z jednym z funduszy kapitału wysokiego ryzyka do końca 2016 r. uruchomionych zostanie blisko 16 tys. paczkomatów w większości krajów europejskich. Cały czas prowadzone są także prace nad kolejnymi generacjami paczkomatów, zawierającymi w sobie coraz to nowsze funkcje, np. bankomatu. Być może w niedalekiej przyszłości doprowadzi to do powstania urządzeń, które będą mogły z powodzeniem zastąpić część mniejszych, nierentownych placówek pocztowych (Dębek, 2013).

Trudno oczywiście przewidzieć, w jakim stopniu uda się zrealizować te jakże odważne i ambitne plany. Działania podejmowane przez firmę InPost zdecydowanie wykraczają bowiem poza prostą próbę antycypowania zmian w otoczeniu przedsiębiorstwa. W tym przypadku należałoby raczej mówić o chęci aktywnego oddziaływania na to otoczenie oraz kształtowania zachodzących w nim procesów. Taka postawa jest niewątpliwie najlepszą wizytówką każdej przedsiębiorczej organizacji. I choć nie gwarantuje ona jeszcze końcowego sukcesu, to przynajmniej stwarza realne szanse wybicia się ponad otaczającą przeciętność.

\section{Zakończenie}

Narastająca turbulentność otoczenia współczesnych przedsiębiorstw stawia konkretne i niejednokrotnie bardzo trudne wyzwania przed menedżerami XXI w. W takich warunkach do przetrwania na rynku nie wystarcza bowiem sama tylko umiejętność szybkiego dostosowywania się do nieustannie zachodzących zmian. W wielu wypadkach nieodzowna wręcz staje się sztuka antycypowania takich zmian oraz podejmowania działań wyprzedzających.

Rozważania zawarte w niniejszym opracowaniu oraz przedstawiony przykład działalności firmy InPost w pełni potwierdzają zatem tezę, że przedsiębiorczość - rozumiana jako umiejętność dostrzegania sposobności w otoczeniu oraz ich wykorzystywania - jest najlepszym i najprostszym lekarstwem na większość problemów, z którymi przychodzi zmierzyć się współczesnym przedsiębiorstwom.

W tym kontekście trudno zatem nie dostrzec roli, jaką odgrywa edukacja w zakresie przedsiębiorczości, realizowana obecnie na różnych etapach kształcenia: szkół ponadgimnazjalnych, wyższych uczelni, a niekiedy nawet studiów doktoranckich. Wbrew wielu obiegowym opiniom, kształtowanie postaw przedsiębiorczych nieodzowne jest także wśród studentów szeroko pojmowanych kierunków ekonomicznych. Przyszli menedżerowie powinni bowiem nie tylko mieć bogaty zasób wiedzy teoretycznej, ale także odznaczać się odpowiednim stanem umysłu, umożliwiającym im skuteczne działanie w praktyce gospodarczej. 


\section{Literatura \\ References}

Anderson, C. (2011). Za darmo. Przyszłość najbardziej radykalnej z cen. Kraków: Społeczny Instytut Wydawniczy Znak.

Ansoff, H.I. (1985). Zarządzanie strategiczne. Warszawa: Państwowe Wydawnictwo Ekonomiczne.

Blaug, M. (1994). Teoria ekonomii. Ujęcie retrospektywne. Warszawa: Wydawnictwo Naukowe PWN.

Bławat, F. (2003). Przedsiębiorca w teorii przedsiębiorczości i praktyce małych firm. Gdańsk: Gdańskie Towarzystwo Naukowe.

Bogdanienko, J. (2008). W pogoni za nowoczesnością. Wybrane aspekty tworzenia i wprowadzania zmian. Toruń: TNOiK „Dom Organizatora”.

Bratnicki, M. (2007). Renta przedsiębiorczości w statycznych i dynamicznych otoczeniach. W: M. Laszuk (red.), Przedsiębiorczy menedżer w przedsiębiorczej organizacji. Księga Jubileuszowa z okazji 70-lecia urodzin oraz 50-lecia pracy zawodowej Profesora Jana D. Antoszkiewicza. Warszawa: Oficyna Wydawnicza SGH, 59-76.

Cieślik, J. (2011). Czy polscy menedżerowie są przygotowani do konkurencji na rynkach Unii Europejskiej? W: W. Kieżun (red.), Krytycznie i twórczo o zarzq̨dzaniu. Wybrane problemy. Warszawa: Wydawnictwo Wolters Kluwer, 239-245.

Conway, S., Steward, F. (2009). Managing and Shaping Innovation. Oxford-New York: Oxford University Press.

Dębek, K. (2013, 22 września). Paczkomatem w kosmos. Forbes. Pozyskano z: http://www.forbes.pl/ artykuly/sekcje/Strategie/paczkomatem-w-kosmos, 30428,1

Dodgson, M., Gann, D., Salter, A. (2008). The Management of Technological Innovation. Strategy and Practice. Oxford-New York: Oxford University Press.

Drucker, P.F. (1992). Innowacja i przedsiębiorczość. Warszawa: Państwowe Wydawnictwo Ekonomiczne.

Drucker, P.F. (1995). Zarządzanie w czasach burzliwych. Warszawa-Kraków: Nowoczesność, Czytelnik i Akademia Ekonomiczna w Krakowie.

Foster, R., Kaplan, S. (2003). Twórcza destrukcja. Dlaczego firmy nastawione na stopniowe ulepszanie swojej działalności nie mają szansy przetrwać i jak je skutecznie przekształcać. Łódź: Wydawnictwo Galaktyka.

Gaweł, A. (2013). Proces przedsiębiorczy. Tworzenie nowych przedsiębiorstw. Warszawa: Wydawnictwo Difin.

Gierszewska, G., Romanowska, M. (2009). Analiza strategiczna przedsiębiorstwa. wyd. 4 zmienione. Warszawa: Polskie Wydawnictwo Ekonomiczne.

Glinka, B. (2008). Kulturowe uwarunkowania przedsiębiorczości w Polsce. Warszawa: Polskie Wydawnictwo Ekonomiczne.

InPost wygrywa z pocztą spór o blaszki (2013, 22 września). Dziennik Gazeta Prawna. Pozyskano z: http://biznes.gazetaprawna.pl/artykuly/587991,inpost_wygrywa_z_poczta_spor_o_blaszki.html.

Jasiński, B. (2005). Turbulencja otoczenia. W: R. Krupski (red.), Zarządzanie przedsiębiorstwem w turbulentnym otoczeniu. Warszawa: Polskie Wydawnictwo Ekonomiczne, 15-21.

Kotler, P., Caslione, J.A. (2009). Chaos. Zarzaddzanie i marketing w erze turbulencji. Warszawa: Wydawnictwo MT Biznes.

Koźmiński, A.K. (2004). Zarządzanie w warunkach niepewności. Podręcznik dla zaawansowanych. Warszawa: Wydawnictwo Naukowe PWN.

Krupski, R. (2005). Elastyczność celów i strategii. W: R. Krupski (red.), Zarządzanie przedsiębiorstwem w turbulentnym otoczeniu. Warszawa: Polskie Wydawnictwo Ekonomiczne, 48-73.

Kurczewska, A. (2013). Przedsiębiorczość jako proces współoddziaływania sposobności i intencji przedsiębiorczych. Warszawa: Polskie Wydawnictwo Ekonomiczne.

Matusiak, K.B. (2006). Rozwój systemów wsparcia przedsiębiorczości: przesłanki, polityka i instytucje. Radom-Łódź: Wydawnictwo Instytutu Technologii Eksploatacji - PIB. 
Mączyńska, E. (2010). Przedsiębiorstwa wobec kryzysu i naruszonej równowagi. W: R. Sobiecki, J.W. Pietrewicz (red.), Przedsiębiorstwa a kryzys globalny. Warszawa: Oficyna Wydawnicza SGH, 199-220.

Miączyński, P. Kostrzewski, L. (2013, 20 września). Przetarg dla Poczty Polskiej. Inni są bez szans. Gazeta Wyborcza. Pozyskano z: http://wyborcza.biz/biznes/1,101562,10873036, Przetarg_dla_Poczty_Polskiej_Inni_sa_bez_szans.html

Obłój, K. (2007). O zarządzaniu refleksyjnie. Warszawa: Wydawnictwo MT Biznes.

Penc, J. (2003). Zarzadzanie w warunkach globalizacji. Warszawa: Wydawnictwo Difin.

Pierścionek, Z. (2006). Strategie konkurencji i rozwoju przedsiębiorstwa. Warszawa: Wydawnictwo Naukowe PWN.

Pochłopień, J. (2013, 22 września). Jedenaście miliardów po raz pierwszy. Forbes. Pozyskano z: http:// 100najbogatszychpolakow.forbes.pl/jedenascie-miliardow-po-raz-pierwszy-najbogatsi-polacy2013, artykuly,139968,1,1.html.

Podręcznik Oslo (2008). Pomiar działalności naukowej i technicznej. Zasady gromadzenia i interpretacji danych dotyczacych innowacji. Wydanie trzecie. Warszawa: OECD, Eurostat i MNiSW.

Popławski, W. (2008). Istota i uwarunkowania współpracy w budowaniu potencjału innowacyjnego przedsiębiorstw. W: W. Popławski, A. Sudolska, M. Zastempowski (red.), Wspólpraca przedsiębiorstw $w$ Polsce w procesie budowania ich potencjatu innowacyjnego. Torun: TNOiK „Dom Organizatora”, 13-41.

Shane, S., Venkataraman, S. (2000). The Promise of Entrepreneurship as a Field of Research. Academy of Management Review, 25(1), 217-226.

Sudoł, S. (2006). Przedsiębiorstwo. Podstawy nauki o przedsiębiorstwie. Zarządzanie przedsiębiorstwem. wyd. 3. Warszawa: Polskie Wydawnictwo Ekonomiczne.

Sudoł, S. (2008). Przedsiębiorczość - jej pojmowanie, typy i czynniki ją kształtujące. Problemy zarzadzania, 6(2), 9-26.

Szymański, W. (2011). Niepewność i niestabilność gospodarcza. Gwattowny wzrost i co dalej? Warszawa: Wydawnictwo Difin.

Targalski, J. (2009). Przedsiębiorczość - istota i znaczenie. W: J. Targalski, A. Francik (red.), Przedsiębiorczość i zarządzanie firma. Teoria i praktyka. Warszawa: Wydawnictwo C.H. Beck, 13-33.

Vahs, D., Burmester, R. (2005). Innovationsmanagement. Von der Produktidee zur erfolgreichen Vermarktung. 3. Auflage. Stuttgart: Schaffer-Poeschel Verlag.

Wachowiak, P. (2007). Przedsiębiorczość - cecha profesjonalnego menedżera. W: M. Laszuk (red.), Przedsiębiorczy menedżer $w$ przedsiębiorczej organizacji. Księga Jubileuszowa z okazji 70-lecia urodzin oraz 50-lecia pracy zawodowej Profesora Jana D. Antoszkiewicza. Warszawa: Oficyna Wydawnicza SGH, 147-153.

Wickham, P.A. (2004). Strategic Entrepreneurship. Eaglewood Cliffs: Prentice Hall.

Wolański, R. (2013). Wpływ otoczenia finansowego na konkurencyjność matych i średnich przedsiębiorstw. Warszawa: Wydawnictwo Wolters Kluwer.

Zorska, A. (2011). Koncepcja twórczej destrukcji J.A. Schumpetera i jej odniesienie do przemian gospodarczych w dobie obecnej rewolucji naukowo-technicznej. W: A. Zorska (red.), Chaos czy twórcza destrukcja? Ku nowym modelom w gospodarce i polityce. Warszawa: Oficyna Wydawnicza SGH, 19-54.

Lukasz Wściubiak, dr inż., Uniwersytet Ekonomiczny w Poznaniu, Katedra Zarządzania i Analizy Zasobów Przedsiębiorstwa.

Dr inż. Łukasz Wściubiak jest adiunktem w Katedrze Zarządzania i Analizy Zasobów Przedsiębiorstwa Uniwersytetu Ekonomicznego w Poznaniu. Jego zainteresowania naukowe koncentrują się wokół zagadnień przedsiębiorczości, innowacji, zarządzania własnością intelektualną oraz transferu technologii z nauki do biznesu. 
Lukasz Wściubiak, PhD, a lecturer in the Department of Management and Enterprise Resources Analysis at the Poznan University of Economics.

Author's research interests are focused on the issues of entrepreneurship, innovation, intellectual property management and the transfer of university-industry technology.

Adres/Address: Uniwersytet Ekonomiczny w Poznaniu

Al. Niepodległości 10

61-875 Poznań, Polska

e-mail: lukasz.wsciubiak@ue.poznan.pl 